\title{
PREDIKSI KINERJA MESIN DIESEL DENGAN BAHAN BAKAR BIODIESEL-SOLAR MENGGUNAKAN ARTIFICIAL NEURAL NETWORK
}

\author{
Husin Ibrahim $^{1}$, A.H Sebayang ${ }^{1}$, S. Dharma ${ }^{1}$ dan A.S. Silitonga ${ }^{1.2}$ \\ ${ }^{1}$ Jurusan Teknik Mesin, Politeknik Negeri Medan, Medan \\ husinibrahim@yahoo.com \\ ${ }^{2}$ Jurusan Teknik Mesin, Universitas Syiah Kuala, Banda Aceh
}

\begin{abstract}
ABSTRAK
Tulisan ini meneliti kinerja mesin diesel satu silinder menggunakan campuran bahan bakar biodiesel randu dengan solar. Tes dilakukan dengan berbagai perbandingan biodiesel-diesel (B10, B20 dan B30). Sebuah model artificial neural network (ANN) yang didasarkan pada algoritma back-propagasi standar digunakan untuk memprediksi kinerja mesin menggunakan MATLAB. Untuk memperoleh data untuk pelatihan dan pengujian yang diusulkan ANN, kecepatan mesin yang berbeda (1400-2200 rpm) dipilih sebagai parameter masukan, sedangkan kinerja mesin (BSFC dan BTE) dipilih sebagai parameter keluaran untuk ANN pemodelan dari mesin diesel. Kinerja mesin (BSFC dan BTE) ANN telah divalidasi dengan membandingkan hasil prediksi dengan hasil eksperimen. Hasil penelitian menunjukkan bahwa koefisien korelasi BSFC dan BTE masing masing adalah 0,99249 dan 0,99457. Nilai MAPE (mean absolute persentase kesalahan) BSFC dan BTE adalah 0,57467 dan 0,33424 dan root mean square (RSME) nilai di bawah $5 \%$ oleh model, yang diterima. Studi ini menunjukkan bahwa pemodelan teknik sebagai pendekatan dalam energi alternatif dapat memberikan peningkatan keuntungan dari kehandalan dalam prediksi kinerja mesin pembakaran dalam.
\end{abstract}

Kata kunci: biodiesel randu, mesin diesel, kinerja mesin, Artificial neural network

\section{PENDAHULUAN}

Pada saat ini penelitian tentang energi terbarukan banyak dilakukan oleh peneliti untuk mencari bahan bakar alternatif sebagai pengganti bahan bakar fossil dengan pertimbangan ramah lingkungan (Sebayang et al., 2016). Untuk memenuhi peraturan emisi gas buang, bahan bakar tebarukan seperti biofuel yang meliputi bioethanol, biodiesel, dimetil eter (DME) dan biogas adalah bahan bakar terbarukan yang dapat mengurangi polusi udara.

Biofuel, khususnya biodiesel, yang didefenisikan sebagai ester monoalkil dari asam lemak disintesis dari minyak nabati maupun lemak hewani (Dharma et al., 2016). Saat ini, sekitar 95\% dari biodiesel global berasal dari minyak nabati seperti rapeseed (84\%), minyak bunga matahari (13\%), minyak sawit (1\%), minyak kedelai dan lain-lain (2\%) (Atabani et al., 2012). Namun, penggunaan tanaman sebagai bahan pangan secara berkelanjutan dikhawatirkan akan memiliki dampak buruk terhadap ketersediaan pangan (Teoh et al., 2014). Masalah kekurangan bahan pangan atau kelaparan sangat serius, terutama di negara-negara berkembang, mungkin timbul karena banyak memanfaatkan daerah lahan yang tersedia. Selain itu, dampak lingkungan dan ketidakseimbangan ekologi juga merupakan efek dari kerusakan hutan untuk tujuan perkebunan sehingga dapat menyebabkan kerusakan kehidupan pada satwa liar.

Untuk menghindari masalah diatas, maka solusi mengeksploitasi minyak dari bahan non pangan sedang dipertimbangkan. Sumber minyak dari bahan baku non pangan mendapatkan perhatian dunia karena tidak cocok untuk konsumsi manusia, sehingga menghilangkan persaingan antara kebutuhan bahan bakar dan bahan pangan. Oleh karena itu, minyak dari bahan baku non pangan lebih ramah lingkungan dan kompetitif dengan minyak nabati. Produksi biodiesel dari tanaman non pangan dianggap sebagai generasi kedua dari bahan baku biodiesel. Bahan baku ini antara 
lain adalah Jatropha curcas (jarak pagar), Calophyllum inophyllum (nyamplung), Ceiba pentandra (randu), Karanja, Neem, Jojoba, dan biji karet.

Penerapan bioediesel dalam mesin CI telah dipelajari dan diuji melalui parameter kinerja mesin seperti, efisiensi termal (BTE) dan konsumsi bahan bakar spesifik (BSFC). Sebagai bahan bakar pengganti diesel, bahan bakar campuran biodiesel-diesel dapat meningkatkan kinerja mesin, seperti dikemukakan oleh beberapa peneliti. Teoh et al. (2015) melaporkan bahwa biofuel yang berasal dari limbah palm oil metil ester (POME) dicampur dengan diesel dapat digunakan secara memuaskan dalam mesin diesel yang tidak dimodifikasi. Selain itu, Ong et al. (2014) melakukan penelitian menggunakan bahan bakar campuran biodiesel-diesel dari bahan baku Jatropa curcas (jarak pagar), Calophyllum inophyllum (nyamplung) dan Ceiba pentandra (randu) pada mesin diesel. Kinerja mesin menunjukkan bahwa penggunaan bahan bakar campuran biodiesel-diesel cocok untuk digunakan pada mesin diesel.

Kinerja mesin diesel dapat diperoleh melalui percobaan dengan memvariasikan kecepatan dan bahan bakar campuran biodiesel randu-diesel. Ada banyak faktor yang mempengaruhi untuk mendapatkan kinerja mesin yang optimal seperti rasio bahan bakar campuran, kecepatan mesin, waktu dan biaya operasional. Oleh karena itu, perlu untuk memprediksi faktor-faktor yang bertujuan untuk meminimalkan waktu dan biaya operasional. Artificial neural network (ANN) adalah alat statistik yang digunakan untuk mengetahui pengaruh baik variabel independen atau kombinasi dari variabel independen terhadap variabel dependen dari proses.

Banyak metode telah dikemukakan dan digunakan untuk mendapatkan hasil prediksi yang akurat. Salah satunya adalah metode artificial neural network $(A N N)$ yang mengadopsi sistem pembelajaran pada otak manusia. Metode ini mampu memecahkan masalah nonlinier yang kompleks dan sulit untuk diselesaikan dengan matematika konvensional maupun pendekatan statistik.

$A N N$ dapat digunakan untuk memprediksi parameter operasi untuk mencapai hasil kinerja mesin maksimal dengan cara model matematika. Penggunaan hasil $A N N$ dapat mempersingkat waktu dan penghematan biaya yang signifikan dengan mengutak-atik parameter operasi, dan ini mengurangi sejumlah besar percobaan yang mahal seperti waktu, biaya dan usaha.

Dalam penelitian ini, campuran biodiesel randu-diesel yang berbeda dan variasi kecepatan mesin diteliti. Data eksperimen yang diperoleh digunakan untuk melatih dan menguji model ANN untuk memprediksi konsumsi bahan bakar spesifik (BSFC) dan efisiensi termal (BTE).

\section{Artificial neural network (ANN) model}

Artificial neural network (ANN) adalah teknik kecerdasan buatan terinspirasi oleh sistem saraf manusia dan umumnya digunakan untuk pemodelan dan mengoptimalkan fenomena yang kompleks yang melibatkan sejumlah besar variabel proses (Kamairudin et al., 2015; Siswantoro et al., 2016). Dalam pemograman ANN yang dibuat berdasarkan dari cara kerja otak manusia di asumsikan secara sederhana seperti gambar berikut. Dimana sinyal input $\mathrm{x}$ dikalikan dengan bobot yang bersesuaian $\mathrm{W}$. Kemudian seluruh perkalian dari $\mathrm{x}_{\mathrm{n}}$ dan $\mathrm{W}_{\mathrm{n}}$ dijumlahkan dan dilakukan ke fungsi transfer untuk kemudian didapatkan keluaran $\mathrm{F}(\mathrm{x}, \mathrm{W})$. 


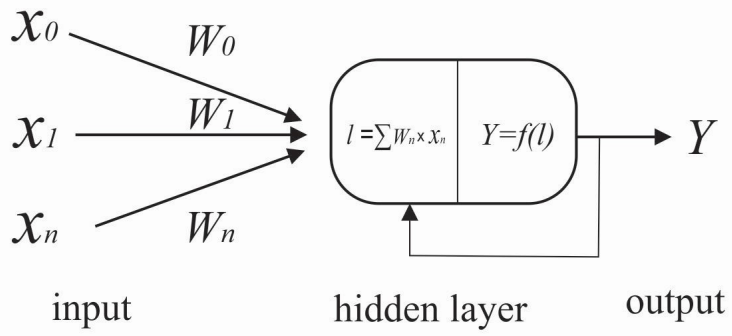

Gambar 1. Model neuron tiruan

ANN dapat digunakan sebagai prediksi dan optimasi model untuk berbagai aplikasi. Kemampuan prediksi ANN ditentukan berdasarkan data eksperimen dan kemudian divalidasi oleh data independen (Kiani et al., 2010). ANN dapat digunakan untuk memecahkan masalah non-linear dengan mengevaluasi hubungan antara parameter input dan output bahkan ketika data yang kompleks dan tidak lengkap (Ismail et al., 2012). ANN memiliki kemampuan untuk mempelajari kembali dalam rangka meningkatkan produksi ketika data baru tersedia (Najafi et al., 2009). Dengan majunya teknologi komputer, ANN sekarang banyak digunakan dalam berbagai disiplin ilmu penelitian ilmiah seperti teknik mesin, teknik kimia dan energi terbarukan (Ayodele \& Cheng, 2015; Pelletier et al., 2016).

Banyak penelitian telah dilakukan untuk memprediksi parameter performansi mesin menggunakan ANN. Penggunaan ANN untuk pemodelan pengoperasian mesin pembakaran dalam yaitu untuk memprediksi kinerja mesin seperti: daya mesin, konsumsi bahan bakar spesifik dan efisiensi termal mesin diesel.

Javed et al., (2015) memprediksi kinerja dan emisi karakteristik jarak metil ester yang dicampur dengan hidrogen menggunakan artificial neural network, dari penelitian tersebut diketahui bahwa artificial neural network $(A N N)$ adalah alat yang baik untuk simulasi dan prediksi mesin dengan menggunakan bahan bakar ganda hidrogen dan biodiesel Jatropha. Kumar et al., (2016) melaporkan bahwa penggunaan ANN dengan persepsi multilayer (MLP) dan radial fungsi dasar (RBF) menunjukkan bahwa hasil prediksi ANN sesuai dengan hasil eksperimen untuk berbagai kondisi kinerja dan emisi dari mesin diesel dengan limbah bahan bakar minyak (WCO).

Pemodelan yang digunakan dalam penelitian ini adalah metode backpropogation. Secara umum arsitektur backpropogation terdiri dari n masukan (ditambah sebuah bias), $\mathrm{p}$ unit sebagai layar tersembunyi (ditambah sebuah bias), serta $\mathrm{m}$ buah unit keluaran. Bias $\mathrm{V}$ dan $\mathrm{W}$ berperilaku seperti bobot dimana output bias ini selalu sama dengan 1 (gambar 2).

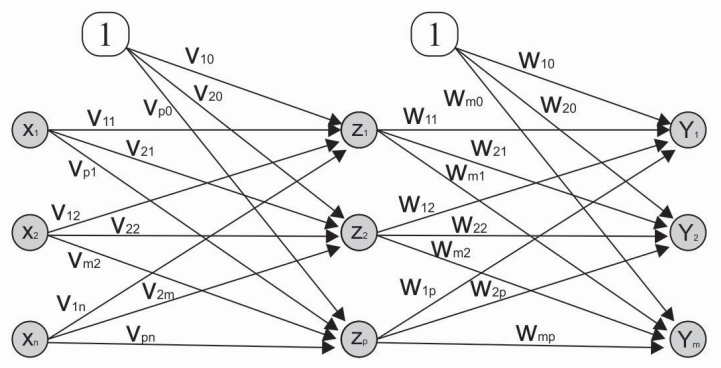

Gambar 2. Arsitektur backpropogation 
Dalam pemodelan ANN di penelitian ini input yang berupa campuran biodiesel dan putaran mesin setelah melalui lapisan tersembunyi (hidden layer) akan langsung diteruskan ke output yang berupa BSFC dan BTE.

\section{Analisa statistik}

Model disimulasikan untuk semua masukan untuk mewujudkan sesuai output masing-masing model. Menggunakan target dan output dari model, koefisien regresi determinasi $\left(\mathrm{R}^{2}\right)$, MAPE dan RMSE dievaluasi menggunakan ungkapan berikut:

Regression determination $\left(R^{2}\right)=\sqrt{1-\left\{\frac{\sum_{i=1}^{n}(T i-)^{2}}{\sum_{i=1}^{n} O i^{2}}\right\}}$

Mean Absolute Percentage Error $(M A P E)=\left\{\frac{100}{n} \sum_{i=1}^{n}\left(\frac{T i-}{T i}\right) \mid\right\}$

Root Mean Squared Error $(R M S E)=\sqrt{\frac{1}{n} \sum_{i=1}^{n}(T i-O i)^{2}}$

dengan $\mathrm{n}$ adalah banyak data, Ti adalah data diperoleh dari eksperimen dan Oi adalah data hasil prediksi. Koefisien determinasi $\left(\mathrm{R}^{2}\right)$, MAPE dan RMSE merupakan indikator kombinasi statistik yang digunakan untuk menilai model ANN. Secara umum, semakin rendah MAPE, RMSE dan semakin tinggi $\mathrm{R}^{2}$ (mendekati atau sama dengan 1) disarankan untuk lebih akuratnya model prediksi ANN. Nilai-nilai indikator ini digunakan pada waktu proses selama iterasi ANN. Disarankan $\mathrm{R}^{2}$ tidak boleh kurang dari $80 \%$.

\section{METODE}

\section{Cara kerja eksperimen}

Percobaan dilakukan dengan menggunakan KOYO R70H, satu selinder, empat langkah, mesin kompresi pengapian (CI). Spesifikasi teknis mesin tercantum dalam Tabel 1. Diagram skematik dari eksperimental set-up diberikan pada Gambar 3.

Tabel 1. Spesifikasi mesin

\begin{tabular}{ll}
\hline Merk & KOYO \\
\hline Model & R70H \\
\hline Jumlah Silinder & Satu silinder poros horizontal \\
\hline Bore & $70 \mathrm{~mm}$ \\
\hline Stroke & $80 \mathrm{~mm}$ \\
\hline Volume silinder & $353 \mathrm{cc}$ \\
\hline Sistem pembakaran & Kamar pusar \\
\hline Tenaga maksimum & $7,2 \mathrm{HP} / 2600 \mathrm{rpm}$ \\
\hline Perbandingan kompresi & $23: 1$ \\
\hline Sistem governor & Mekanis \\
\hline Sistem starting & Dengan engkol \\
\hline Kapasitas oli & 2 liter \\
\hline Berat bersih & $65 \mathrm{~kg}$ \\
\hline
\end{tabular}

Semua biodiesel randu dicampur dengan diesel diuji pada berbagai kecepatan mesin. Mesin CI dimulai menggunakan diesel dan memungkinkan untuk mencapai stabilitas selama 15 menit sebelum mengambil pengamatan. Setelah kondisi mesin stabil dan mencapai steady state, kecepatan mesin dan konsumsi bahan bakar diukur. Pada tahap berikutnya, putaran dan dan 
waktu konsumsi bahan bakar dicatat. Ini akan diamati di sini bahwa semua percobaan dilakukan di bawah kondisi beban penuh. Sebelum mengumpulkan data dari mesin CI berbahan bakar campuran, mesin dioperasikan menggunakan diesel selama jangka waktu tertentu untuk menghapus bahan bakar yang tersisa dari sebelumnya.Tiga percobaan dilakukan untuk setiap percobaan dan nilai rata-rata dari masing-masing parameter ditentukan untuk setiap bahan bakar yang diuji.

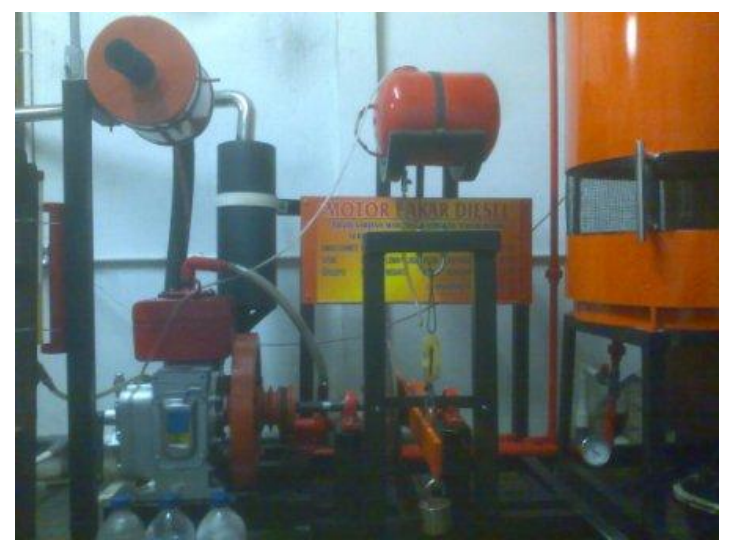

Gambar 3. Diagram skematik setup alat uji

\section{Sifat-sifat bahan bakar diesel dan biodiesel}

Sebelum melakukan percobaan, campuran bahan bakar disiapkan dan dipastikan bahwa campuran bahan bakar homogen. Biodiesel dicampur dengan solar yang diperoleh dari Pertamina dengan cetane number 49,7 sebagai basis solar. Kinerja dari mesin berjalan pada biodiesel yang dicampur dengan diesel (B10, B20 dan B30) diteliti dan dibandingkan dengan bahan bakar diesel. Sifat-sifat bahan bakar diberikan pada Tabel 2. (Ong et al., 2014).

Tabel 2. Sifat-sifat bahan bakar

\begin{tabular}{lllll}
\hline Bahan bakar & $\begin{array}{l}\text { viskositas } \\
(\mathrm{mm} 2 / \mathrm{s})\end{array}$ & $\begin{array}{l}\text { densitas } \\
(\mathrm{kg} / \mathrm{mm} 3)\end{array}$ & $\begin{array}{l}\text { Nilai kalor } \\
(\mathrm{MJ} / \mathrm{kg})\end{array}$ & $\begin{array}{l}\text { Nomor } \\
\text { Cetene }\end{array}$ \\
\hline Solar & 2,91 & 839,0 & 45,82 & 49,7 \\
\hline B10 & 3,51 & 851,3 & 44,47 & 50,2 \\
\hline B20 & 3,58 & 854,0 & 43,15 & 51,7 \\
\hline B30 & 3,96 & 855,0 & 42,85 & 52,4 \\
\hline
\end{tabular}

\section{HASIL DAN PEMBAHASAN}

\section{Konsumsi bahan bakar spesifik (BSFC)}

BSFC dengan variasi kecepatan untuk bahan bakar diesel dan campuran yang berbeda dari B10, B20 dan B30 disajikan pada Gambar 4. Kecenderungan BSFC meningkat sejalan dengan meningkatnya persentasi campuran. BSFC dari B10, B20 dan B30 bahan bakar yang diamati lebih tinggi sebesar 4,3\%, 7,8\% dan 9,3\% dibandingkan dengan bahan bakar diesel, hasil ini sesuai dengan penelitian (Buyukkaya, 2010). Hal ini diyakini bahwa BSFC yang lebih tinggi untuk bahan bakar dicampur adalah karena efek gabungan dari viskositas yang lebih tinggi dan nilai kalori yang lebih rendah dari minyak randu. Silitonga et al., (2015) melaporkan dalam penelitiannya bahwa peningkatan persentase volume biodiesel akan menurunkan nilai kalor dan hal itu menyebabkan meningkatnya nilai BSFC untuk menghasilkan jumlah energi yang sama di mesin dibandingkan dengan bahan bakar diesel. Alasan lain untuk peningkatan BSFC dengan 
biodiesel mungkin perubahan dalam waktu pembakaran disebabkan oleh cetane number yang tinggi pada biodiesel serta perubahan timing injeksi.

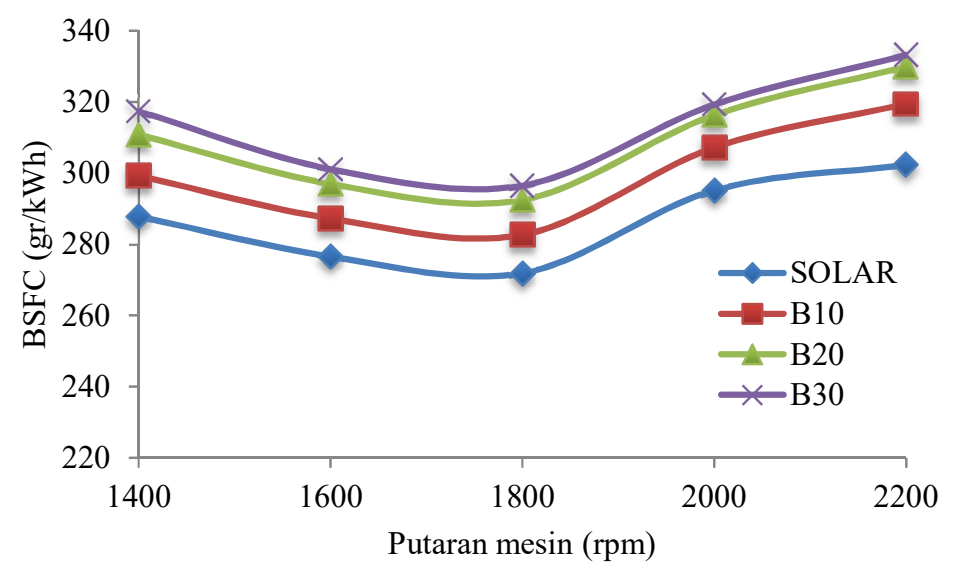

Gambar 4. Grafik konsumsi bahan bakar spesifik terhadap variasi putaran

\section{Efesiensi termal}

Gambar 5 menunjukkan perubahan parameter kinerja sehubungan dengan putaran mesin dengan bahan bakar solar sebagai dasarnya. Semua pengamatan diambil dalam rentang kecepatan 1400$2200 \mathrm{rpm}$ dengan kenaikan dari $200 \mathrm{rpm}$. Hasil penelitian menunjukkan bahwa BTE memiliki kecenderungan menurun dengan meningkatnya persentase bioediesel, hal ini sama dengan study (Yadav et al., 2016). Untuk semua efisiensi termal biodiesel lebih rendah dibandingkan dengan solar murni atas seluruh rentang putaran mesin pada beban penuh. BTE bahan bakar dicampur turun rata-rata sebesar 1,6\% lebih rendah dari pada bahan bakar diesel. Penurunan BTE ini disebabkan peningkatan viskositas bahan bakar campuran. Selain itu, faktor rendahnya nilai kalor dan kepadatan bahan bakar campuran merupakan salah satu faktor yang mempengaruhi rendahnya BTE.

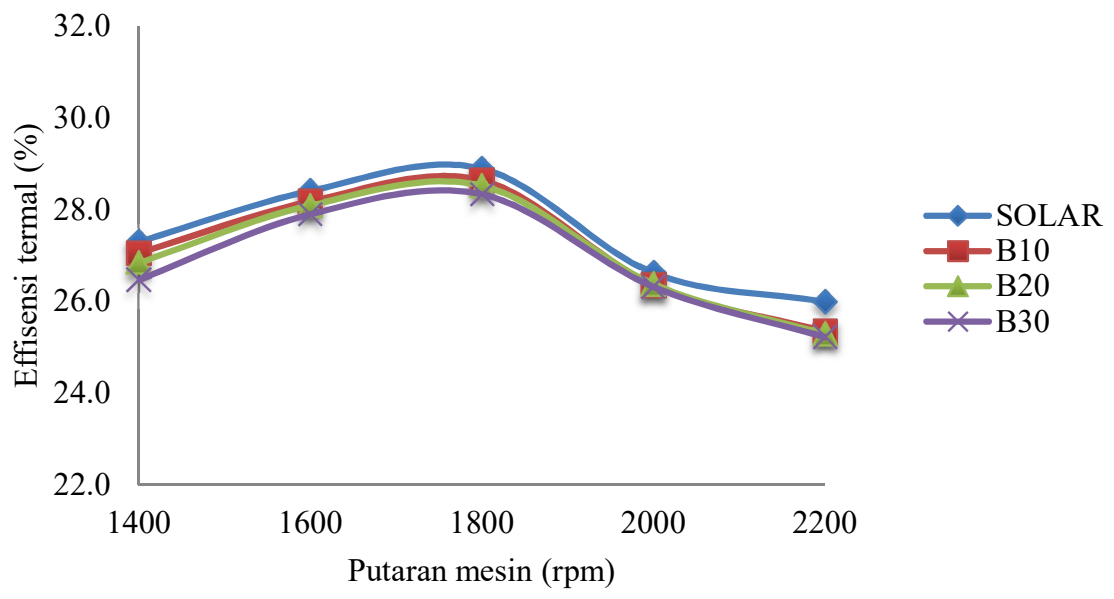

Gambar 5. Grafik efisiensi termal terhadap variasi putaran

\section{ANN model analysis}


Artificial neural network (ANN) berdasarkan karya eksperimental dilakukan untuk membuat model yang digunakan untuk memprediksi kinerja mesin diesel seperti BSFC dan BTE dilakukan menggunakan pemograman Mathlab toolbox. Penggunaan model ANN dianggap cocok untuk pendekatan praktis dan dapat diandalkan untuk masalah non-linear untuk memprediksi kinerja mesin untuk mesin diesel. Model independen awalnya dikembangkan untuk parameter kinerja. Pemanfaatan fasilitas kotak peralatan yang tersedia untuk pemodelan ANN dianggap sebagai cara sederhana untuk mendapatkan hasil yang akurat. Untuk menguji analisa tentang dua model ini, 20 pola yang digunakan, 70\% (14 pola) yang digunakan dalam training set, $15 \%$ (3 pola) di set validasi dan sisanya 15\% (3 pola). Variasi persentase campuran (B10, B20 dan B30 bahan bakar diesel) dan kecepatan mesin sebagai parameter masukan. BSFC dan BTE adalah parameter keluaran untuk kinerja mesin. Percobaan dilakukan untuk setiap operator parameter keluaran yang telah dimasukkan ke dalam sistem jaringan. Hal itu dimaksudkan untuk mendapatkan keluaran yang lebih baik. Pemodelan akan berhenti apabila mendapat hasil $\mathrm{R}$ yang terbesar dan MSE yang masih minimal. Skema representasi dari konfigurasi multi-layer jaringan saraf untuk kedua model ditunjukkan pada Gambar 6.

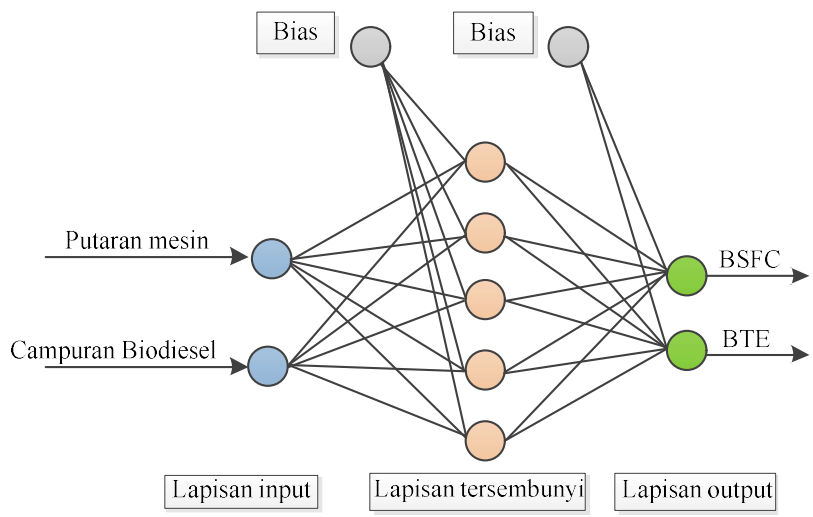

Gambar 6. Arsitektur jaringan saraf dengan 5 lapisan tersembunyi untuk kinerja mesin diesel

Pemilihan jumlah jaringan lapisan tersembunyi memiliki peran dalam mengukur keberhasilan model. Seleksi dilakukan oleh beberapa uji coba, untuk mendapatkan nilai MSE (minimal) dan R (maksimum) yang merupakan indikasi bahwa hasil prediksi model yang akurat. Oleh karena itu, artificial neural network $(A N N)$ dengan 5 lapisan tersembunyi terbukti dapat menghasilkan nilai prediksi yang optimal seperti ditunjukkan pada Tabel 3. Tabel 3 menunjukkan prediksi untuk kedua pendekatan pelatihan dan pengujian yang diperoleh dengan akurasi yang memuaskan.

Hasil eksperimen dibandingkan dengan hasil prediksi untuk parameter kinerja dapat dilihat pada Gambar 7-10. Prediksi ANN dilakukan untuk parameter kinerja seperti konsumsi bahan bakar spesifik (BSFC) dan efisiensi termal (BTE) menghasilkan koefisien korelasi (R) adalah masingmasing sebesar 0,99249 dan 0,9945 dengan

Sementara itu, kesalahan selama proses pembelajaran atau akar-mean square error (RMSE) untuk parameter kinerja BSFC $(2,21543 \mathrm{gr} / \mathrm{kWh})$ dan BTE $(0,12225 \%)$. Sementara itu, mean absolut persentase error (MAPE) untuk BSFC (0,57467\%) dan BTE (0,33424\%). Koefisien regresi determinasi $\mathrm{R}^{2}$ untuk BSFC $(0,9850)$ dan BTE $(0,9890)$.

Hasil analisis menggunakan prediksi ANN diperoleh kesalahan relatif kurang dari 5\% dan nilai ini masih dalam margin kesalahan dapat diterima. 
Tabel 3. Rangkuman hasil prediksi kinerja mesin diesel

\begin{tabular}{lll}
\hline & $\begin{array}{l}\text { BSFC } \\
(\mathrm{g} / \mathrm{kWh})\end{array}$ & $\begin{array}{l}\text { BTE } \\
(\%)\end{array}$ \\
\hline Lapisan tersembunyi & 5 & 5 \\
\hline MSE & 4,90811 & 0,01495 \\
\hline RMSE & 2,21543 & 0,12225 \\
\hline$R^{2}$ & 0,9850 & 0,9890 \\
\hline MAPE $(\%)$ & 0,57467 & 0,33424 \\
\hline
\end{tabular}

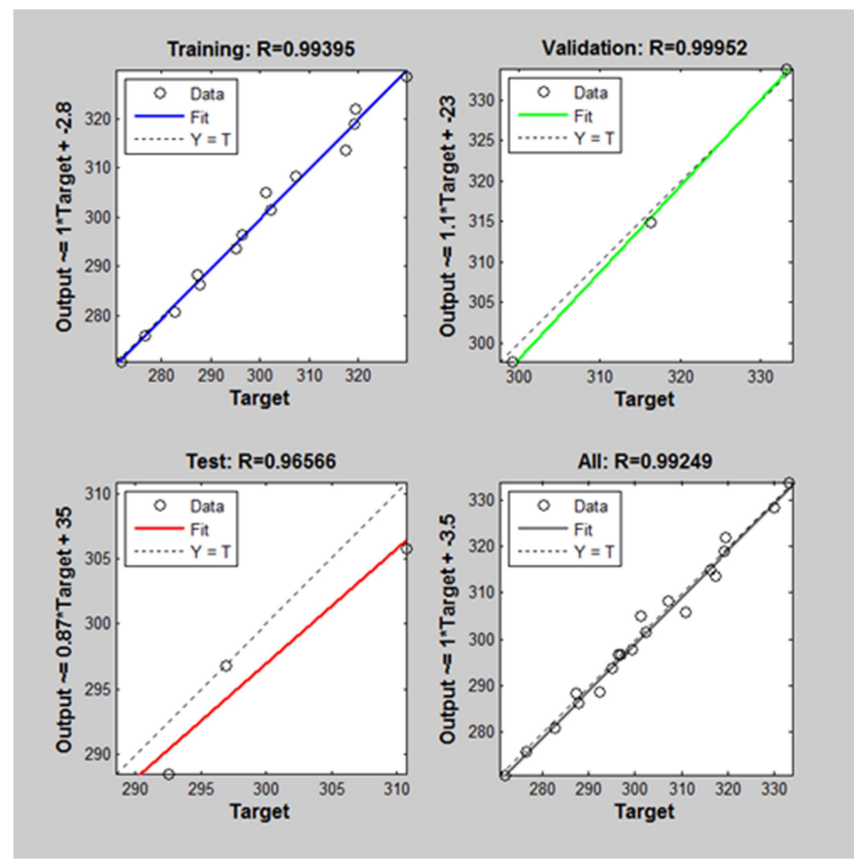

Gambar 7. Grafik regresi prediksi vs hasil experiment untuk BSFC 
Vol. 1, No. 1, April 2017: hlm 48-58

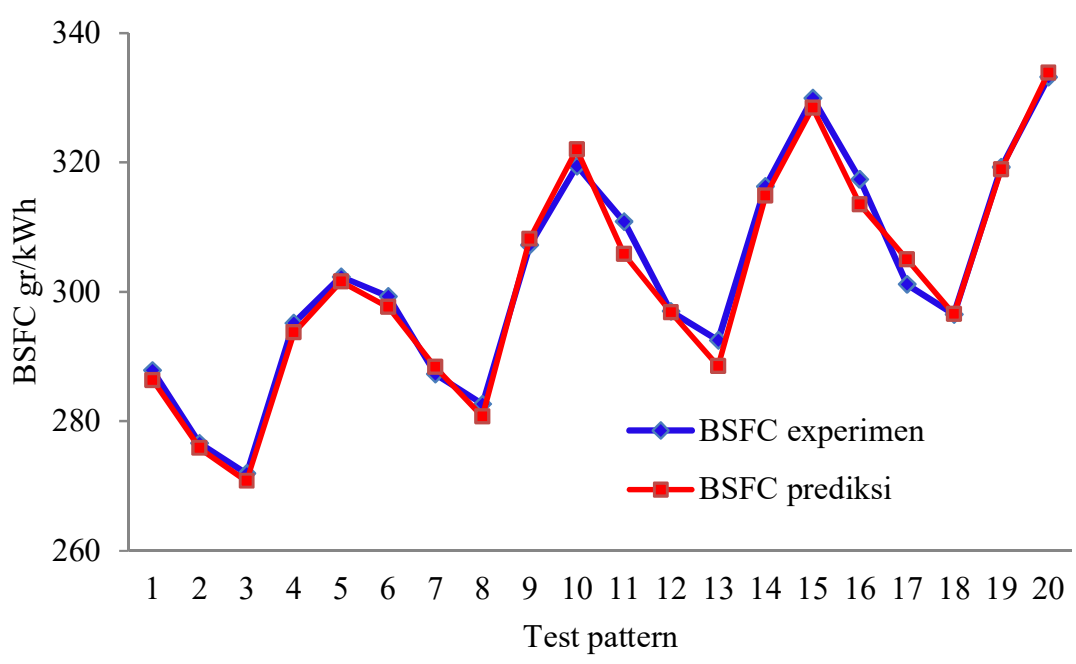

Gambar 8. Perbandingan antara hasil experimen dan data prediksi untuk BSFC

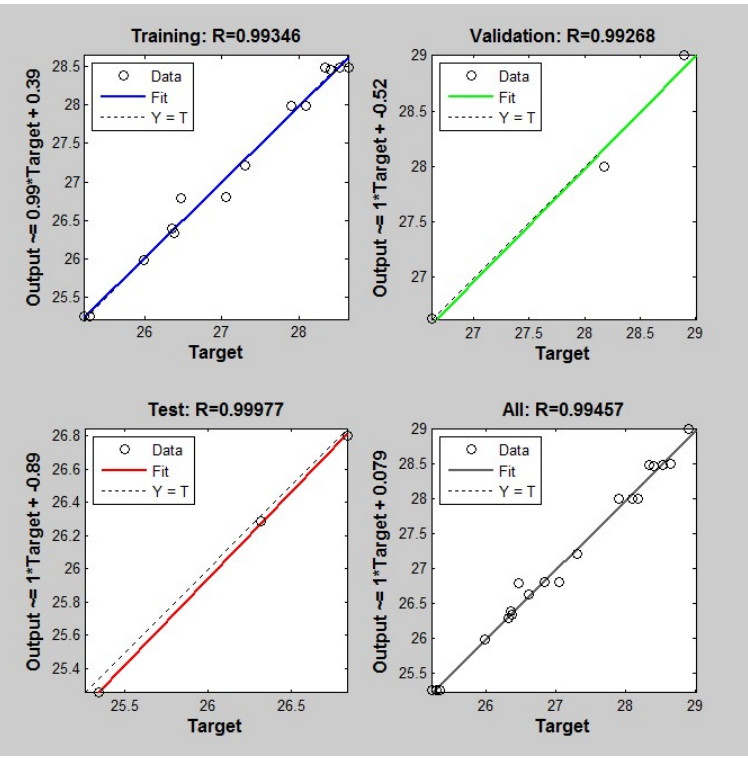

Gambar 9. Grafik regresi prediksi vs hasil experiment untuk BTE 


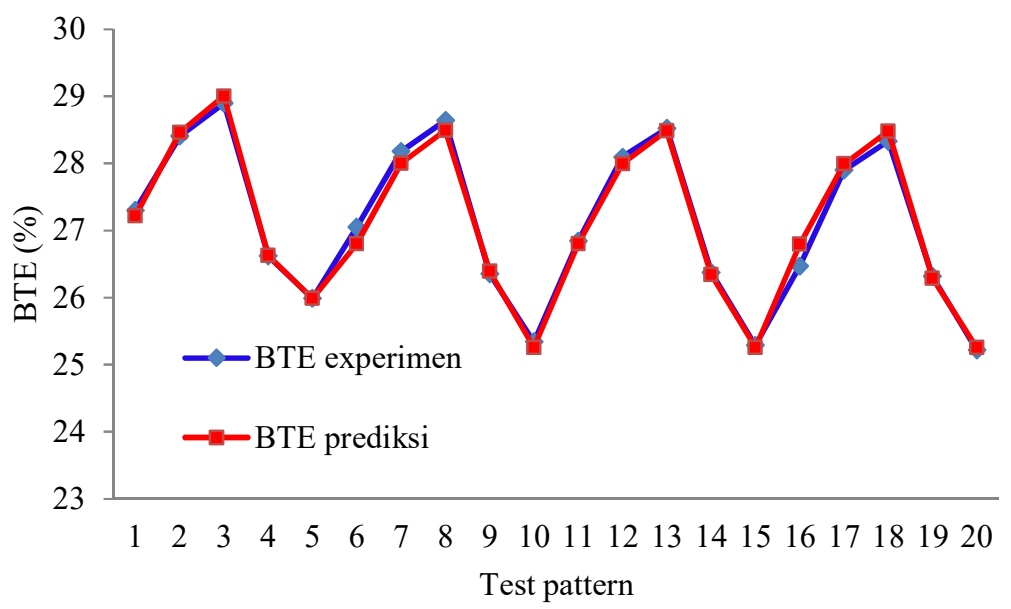

Gambar 10. Perbandingan antara hasil experimen dan data prediksi untuk BTE

\section{KESIMPULAN}

Dalam penelitian ini, pemodelan ANN digunakan untuk prediksi kinerja mesin dengan parameter BSFC dan BTE dari mesin CI yang beroperasi dengan campuran bahan bakar biodiesel randudiesel. Hasil terbaik dalam prediksi BSFC dan BTE diperoleh dengan arsitektur jaringan dari 25-2. Dalam model ANN, koefisien determinasi dari BSFC dan BTE untuk kedua pelatihan dan set pengujian terutama dekat dengan 1. Terbukti pula bahwa hasil ANN diperoleh untuk BSFC dan BTE dalam batas kesalahan yang dapat diterima $(<5 \%)$. Hasil ini menunjukkan bahwa kemampuan belajar dari ANN cukup kuat untuk prediksi BSFC dan BTE. Oleh karena itu, penggunaan ANN sangat dianjurkan untuk prediksi konsumsi bahan bakar spesifik dan efiseiensi termal pada mesin diesel.

\section{REFERENSI}

Atabani, A. E., Silitonga, A. S., Badruddin, I. A., Mahlia, T.I., Masjuki, H., \& Mekhilef, S. (2012). A comprehensive review on biodiesel as an alternative energy resource and its characteristics. Renewable and sustainable energy reviews, 16(4), 2070-2093.

Ayodele, B. V., \& Cheng, C. K. (2015). Modelling and optimization of syngas production from methane dry reforming over ceria-supported cobalt catalyst using artificial neural networks and Box-Behnken design. Journal of Industrial and Engineering Chemistry, 32, 246-258.

Buyukkaya, E. (2010). Effects of biodiesel on a DI diesel engine performance, emission and combustion characteristics. Fuel, 89(10), 3099-3105.

Dharma, S., Ong, H. C., Masjuki, H.H., Sebayang, A.H., \& Silitonga, A.S. (2016). An overview of engine durability and compatibility using biodiesel-bioethanol-diesel blends in compression-ignition engines. Energy Conversion and Management, 128, 66-81.

Ismail, H. M., Ng, H. K., Queck, C. W., \& Gan, S. (2012). Artificial neural networks modelling of engine-out responses for a light-duty diesel engine fuelled with biodiesel blends. Applied Energy, 92, 769-777.

Javed, S., Murthy, Y. S., Baig, R. U., \& Rao, D. P. (2015). Development of ANN model for prediction of performance and emission characteristics of hydrogen dual fueled diesel engine with Jatropha Methyl Ester biodiesel blends. Journal of Natural Gas Science and Engineering, 26, 549-557. 
Kamairudin, N., Gani, S. S. A., Masoumi, H. R. F., Basri, M., Hashim, P., Mokhtar, N. M., \& Lane, M. E. (2015). Modeling of a natural lipstick formulation using an artificial neural network. RSC Advances, 5(84), 68632-68638.

Kiani, M. K. D., Ghobadian, B., Tavakoli, T., Nikbakht, A., \& Najafi, G. (2010). Application of artificial neural networks for the prediction of performance and exhaust emissions in SI engine using ethanol-gasoline blends. Energy, 35(1), 65-69.

Kumar, S., Pai, P. S., Rao, B. S., \& Vijay, G. (2016). Prediction of performance and emission characteristics in a biodiesel engine using WCO ester: a comparative study of neural networks. Soft Computing, 20(7), 2665-2676.

Najafi, G., Ghobadian, B., Tavakoli, T., Buttsworth, D., Yusaf, T., \& Faizollahnejad, M. (2009). Performance and exhaust emissions of a gasoline engine with ethanol blended gasoline fuels using artificial neural network. Applied Energy, 86(5), 630-639.

Ong, H. C., Masjuki, H.H., Mahlia, T.I., Silitonga, A.S., Chong, W., \& Yusaf, T. (2014). Engine performance and emissions using Jatropha curcas, Ceiba pentandra and Calophyllum inophyllum biodiesel in a CI diesel engine. Energy, 69, 427-445.

Pelletier, F., Masson, C., \& Tahan, A. (2016). Wind turbine power curve modelling using artificial neural network. Renewable Energy, 89, 207-214.

Sebayang, A.H., Masjuki, H.H., Ong, H. C., Dharma, S., Silitonga, A.S., Mahlia, T.I., \& Aditiya, H.B. (2016). A perspective on bioethanol production from biomass as alternative fuel for spark ignition engine. RSC Advances, 6(18), 14964-14992.

Silitonga, A.S., Masjuki, H.H., Ong, H. C., How, H., Kusumo, F., Teoh, Y., \& Mahlia, T.I. (2015). Engine Performance, Emission and Combustion in Common Rail Turbocharged Diesel Engine from Jatropha Curcas Using Artificial Neural Network. Technical Paper, 32-0710.

Siswantoro, J., Prabuwono, A. S., Abdullah, A., \& Idrus, B. (2016). A linear model based on Kalman filter for improving neural network classification performance. Expert Systems with Applications, 49, 112-122.

Teoh, Y., Masjuki, H.H., Kalam, M., Amalina, M., \& How, H. (2014). Effects of Jatropha biodiesel on the performance, emissions, and combustion of a converted common-rail diesel engine. RSC Advances, 4(92), 50739-50751.

Teoh, Y., Masjuki, H.H., Noor, I., Ali, B. S., Kalam, M., \& How, H. (2015). Evaluation of a novel biofuel from unwanted waste and its impact on engine performance, emissions, and combustion characteristics in a diesel engine. RSC Advances, 5(53), 42438-42447.

Yadav, A. K., Khan, M. E., Dubey, A. M., \& Pal, A. (2016). Performance and emission characteristics of a transportation diesel engine operated with non-edible vegetable oils biodiesel. Case Studies in Thermal Engineering, 8, 236-244 